функционального состояния сердечно-сосудистой системы для выявления групп студентов со сниженным адаптационным потенциалом. В исследованиях приняло участие 1107 студентов. Из них - 485 девушек, 622 юноши в возрасте 17- 20 лет. Проведена оценка индивидуального здоровья студентов по методике Р. М. Баевского, Г. Л. Апанасенко. На основе пробы Мартине с модификациями разработана методика оценки индивидуальных особенностей кровообращения, позволяющая выявить характер адаптационных нарушений. Выявлено восемь функциональных паттернов реакции системы кровообращения на физическую нагрузку. Разработанная методика позволяет определить лиц с повышенным риском внезапных нарушений гемодинамики, осуществлять контроль уровня функциональной тренированности студентов, подбирать индивидуальные программы физических нагрузок.

Ключевые слова: функциональная проба, адаптационные нарушения, гемодинамика, студенты, методика оценки.

Boyko Anna, Nosovets Olena, Nastenko Evgenii. Algorithm of Assessment of Physical Condition of Students with Functional Patterns of Circulatory System. Objective of work - forming of method of estimation of circulatory system functional states to reveal groups of students with reduced adaptational potential. Materials: 1107 students took part in disquisition. There were 485 girls and 622 boys at the age from 17 to 20 years. Estimation of individual health of students according to the methods of R. M. Baevski and G. L. Apanasenko has been carried out. Methods are based on Martine's test with modifications for assessment of individual peculiarities of circulation, permitting to discover disposition of adaptation breakings. Eight functional patterns of circulatory system reaction on physical loading were uncovered. Developing method allows reveal people with heightened risk of sudden breakings of homodynamic, accomplished control of functional coaching of students.

Key words. Functional test, breaking of adaptation, hemodynamic, students, evaluation method.

Стаття надійшла до редколегії 18.10.2015 p.

\author{
Марія Бондаренко (Рассомагіна), \\ Олександр Бондаренко, \\ Вікторія Кравченко, \\ Микола Макарчук
}

\title{
ЕЕГ аналіз розподілу уваги в лівшів та правшів при проходженні емоційного Струп-тесту на фоні пред'явлення зображень IAPS
}

Оцінювали спектральну потужність та коефіцієнт когерентності основних ритмів ЕЕГ (тета-, альфа-, бетанизькочастотний, бета-високочастотний) під час емоційного Струп-тесту на фоні зображень IAPS у лівшів та правшів із відкритим домінантним і недомінантним оком.

Ключові слова: IAPS, емоційний Струп-тест, домінантне око, недомінантне око.

Постановка наукової проблеми та ї̈ значення. У сучасному світі новітніх технологій масив інформації часто перевантажує органи чуття людини, потік даних є надзвичайно потужним та в рази більшим, ніж це було бодай 10 років тому. Намагаючись утримати рівновагу, гомеостаз і продуктивність протягом робочого дня, людський мозок користується свідомим (довільною) та підсвідомим (мимовільною) фільтром (увагою), щоб нерелевантна ситуація інформації не навантажувала операційну пам' ять. Водночас на сьогодні відомо, що будь-які емоційні стимули, чи то слова [1, 2], чи то картинки [3] спричиняють мимовільне зміщення фокусу уваги. Якщо індивід звертає увагу на емоційні стимули, нерідко вони здатні викликати певні емоції.

Низка нейропсихологічних досліджень засвідчила ЕЕГ кореляти емоцій. Ці особливості ЕЕГ у цілому можна помістити в один із двох доменів: часовий та частотний [4]. У часовому домені йдеться про пов'язані з подією викликані потенціали, а в частотному - про спектральну потужність у різних частотних діапазонах, що залучені в розвиток та підтримку емоційного стану. Спектральна потужність альфа-ритму змінюється залежно від валентності стимулу [5] або під час переживання дискретних емоцій, таких як щастя, печаль і страх [6]. Зокрема, фронтальна асиметрія альфа-ритму

() Бондаренко (Рассомагіна) М., Бондаренко О., Кравченко В., Макарчук М., 2015 
неодноразово відзначалася, як стійкий корелят валентності [7]. Подальші дослідження показали, що фронтальна асиметрія альфа-ритму більше відображає аспекти підхід/уникнення емоцій, ніж валентність як таку [8]. Синхронізація (СПЗП) та десинхронізація, пов'язані з подією спектральної потужності гамма-ритму були пов'язані з деякими емоціями, такими як щастя й смуток [9-11]. СПЗП потужності тета-ритму також модулюється під час зміни емоційного стану [6, 12-14].

Окрім змін спектральної потужності, інтерактивні властивості між парою коливань ЕЕГ, такі як фазова синхронізація та когерентність, були також залучені в розвиток і підтримку емоційних процесів. Наприклад, когерентність ЕЕГ у префронтальних та задніх парах на частоті бета-ритму збільшувалася під час перегляду зображень із високим рівнем збудження [15]. Крім того, збільшення індексу синхронізації гамма-ритму викликане неприємними візуальними стимулами [16]. Схоже, що емоційна інформація не тільки відволікає від основного завдання та до того ж залучає потужний патерн психофізіологічної діяльності. Справді, у наших попередніх дослідженнях показано, що за умови сприйняття емоційної інформації через недомінатне око обстежувані сильно відволікалися на емоційний контекст слова, що пред'являлось у центрі чорного екрана, хоч головним завданням було реагувати на колір слова. Аналіз спектральної потужності свідчить про емоційне збудження, опосередковане генералізованим зростаннм СП тета-ритму, а відносно більша кількість помилок - про погіршення точності виконання завдання [17]. Натомість, сприйняття інформації через домінантне око супроводжується відмінним патерном мозкової активності - зростання СП потужності бетаритму, відсутність помилок, точність виконання завдання [18]. Усі описані вище феномени й дані ставлять перед нами низку нових запитань: чи розповсюджується ефект зорової домінантності щодо сприйняття емоційних стимулів на більш потужні подразники, такі як емоційні картинки, оскільки в повсякденному житті відволікаючі фактори мають вищу модальність, ніж в умовах експерименту.

Мета статті - на основі змін спектральної потужності, когерентних зв'язків основних ритмів ЕЕГ та латентних періодів реакції проаналізувати в право- та ліворуких обстежуваних мозкову обробку вербальних стимулів за умови їх монокулярного сприйняття домінантним і недомінантним оком при проходженні емоційного Струп-тесту, у якому обстежуваним ставилося завдання розпізнавати колір написання слів, не читаючи їх, на фоні картинок різної валентності.

Матеріали й методи дослідження. У дослідженні брали участь 80 студентів обох статей віком 18-22 років. Згідно з профілями міжпівкульної асиметрії, яку визначали за методикою [19], обстежуваних поділено на чотири групи, кожна з яких складалась із 20 осіб. В обстеженні брали участь лише особи 3 коефіцієнтом асиметрії головного мозку $\geq 71 \%$. Дві «домінантні» групи (перша - правші 3 домінантним правим оком; друга - лівші з домінантним лівим оком) виконували завдання, використовуючи домінантне око, інше око було закрите спеціальною пов' язкою, та дві «недомінантні» групи (перша - правші з недомінантним лівим оком; друга - лівші з недомінантним правим оком), які виконували завдання, використовуючи недомінантне око. Зорову домінантність визначали за допомогою тесту на прицілювання Порта (Porta Sighting Test) [20]. Обстежувані виконували чотири завдання (T1-T4), що чергувалися зі станом спокою. У чотирьох тестах завдання було однакове виконати так званий «емоційний» тест, що включав реакції на емоційно забарвлені та нейтральні слова. У всіх тестах обстежуваним слід було визначити, яким кольором написане слово, не читаючи його, на фоні різних картинок. При цьому обстежувані повинні натиснути певну клавішу правою рукою, якщо слово було написане червоними літерами, або лівою - якщо слово написано зеленими літерами. У всіх тестах завдання було однакове, відрізнялося лише валентністю фонової картинки. У якості фонових картинок використовували фотографії з банку Міжнародної системи афективних зображень (IAPS) [21]. Із цього ряду зображень відібрано чотири групи стимулів: позитивні (для першого тесту (Т1)), еротичні (для другого тесту (Т2)), нейтральні (для третього тесту ((Т3) та негативні (для четвертого тесту ((Т4).

Реєстрували латентні періоди (ЛП) реакції (середній - для правої й лівої рук, окремо для різних типів слів - нейтральних та емоційних на фоні чотирьох блоків картинок) і кількість помилкових реакцій у кожному тесті.

У ході експерименту при виконанні чотирьох тестів у всіх обстежуваних реєстрували ЕЕГ за такою схемою: стан спокою (СП 1) - 2 хв, під час виконання Т1 - 2 хв, стан спокою (СП 2) - 2 хв, під 
час виконання Т2 - 2 хв, стан спокою (СП 3) - 2 хв, під час виконання Т3 - 2 хв, стан спокою (СП 4) - 2 хв, під час виконання Т4 - 2 хв. ЕЕГ реєстрували, використовуючи діагностичний комплект «НейронСпектр» (ООО «Нейрософт», Росія), ЕЕГ реєстрували монополярно, як референтний використовували іпсілатеральний вушний електрод. Електроди розміщували за міжнародною системою 10-20 \% у 16 симетричних точках поверхні голови: префронтальних (Fp1/Fp2), середньофронтальних (F3/F4), латеральнофронтальних (F7/F8), центральних (C3/C4), передніх (T3/T4) і задніх скроневих (T5/T6), тім'яних (P3/P4) та потиличних $(\mathrm{O} 1 / \mathrm{O} 2)$. Для аналізу ЕЕГ-показників використовували лише безартефактні фрагменти запису. Із допомогою програмного забезпечення «Нейрон Спектр» на основі алгоритму швидкого перетворення Фур'є обчислювали спектральну потужність (СП) для наступних частотних діапазонів: тета (4,0-7,9 Гц), альфа (8,0-12,9 Гц), бета-низькочастотний $(13,0-19,9$ Гц), бета-високочастотний (20,0-35,0 Гц). Епоха аналізу становила 2,56 c, епоха перекриття - 1,28 c, смуга пропускання - від 1 до 35 Гц. Визначали коефіцієнт когерентності (КК) у діапазонах указаних вище ритмів. Для аналізу брали коефіцієнти когерентності, що перевищували 0,5. Для оцінки рівня внутрішньопівкульної інтеграції використовували такі пари відведень: Fp1-F3, Fp2-F4, F7-T3, F3C3, F4-C4, F8-T4, T3-T5, C3-P3, C4-P4, T4-T6, P3-O1, P4-O2. C4-O2, Fp1-T3, Fp2-T4, T3-O1, T4O2; міжпівкульну інтеграцію оцінювали на основі КК між такими парами відведень: Fp1-Fp2, F3-F4, C3-C4, P3-P4, O1-O2, F7-F8, T3-T4, T5-T6.

Статистичний аналіз даних проводили за допомогою пакета STATISTICA 7,0 (Statsoft, USA, 2004). Оскільки розподіл більшості показників, отриманих у цих дослідженнях, був відмінним від нормального (за критерієм Лілліфора), при порівнянні залежних вибірок застосували непараметричний Т-критерій знакових рангів Вілкоксона, для незалежних вибірок - Мана-Уітні. Критичний рівень значущості міжгрупових відмінностей при перевірці статистичної гіпотези приймали рівним $\mathrm{p}=0,05$. Для опису вибіркового розподілу вказували медіани й міжквартильний розкид (Me $[25 \% ; 75 \%])$.

Виклад основного матеріалу й обгрунтування отриманих результатів дослідження. Нагадаємо, що обстежуваних поділено за зоровою домінантністю, завдання в різних групах не відрізнялися, лише домінантність відкритого ока під час монокулярного сприйняття відігравала ключову роль.

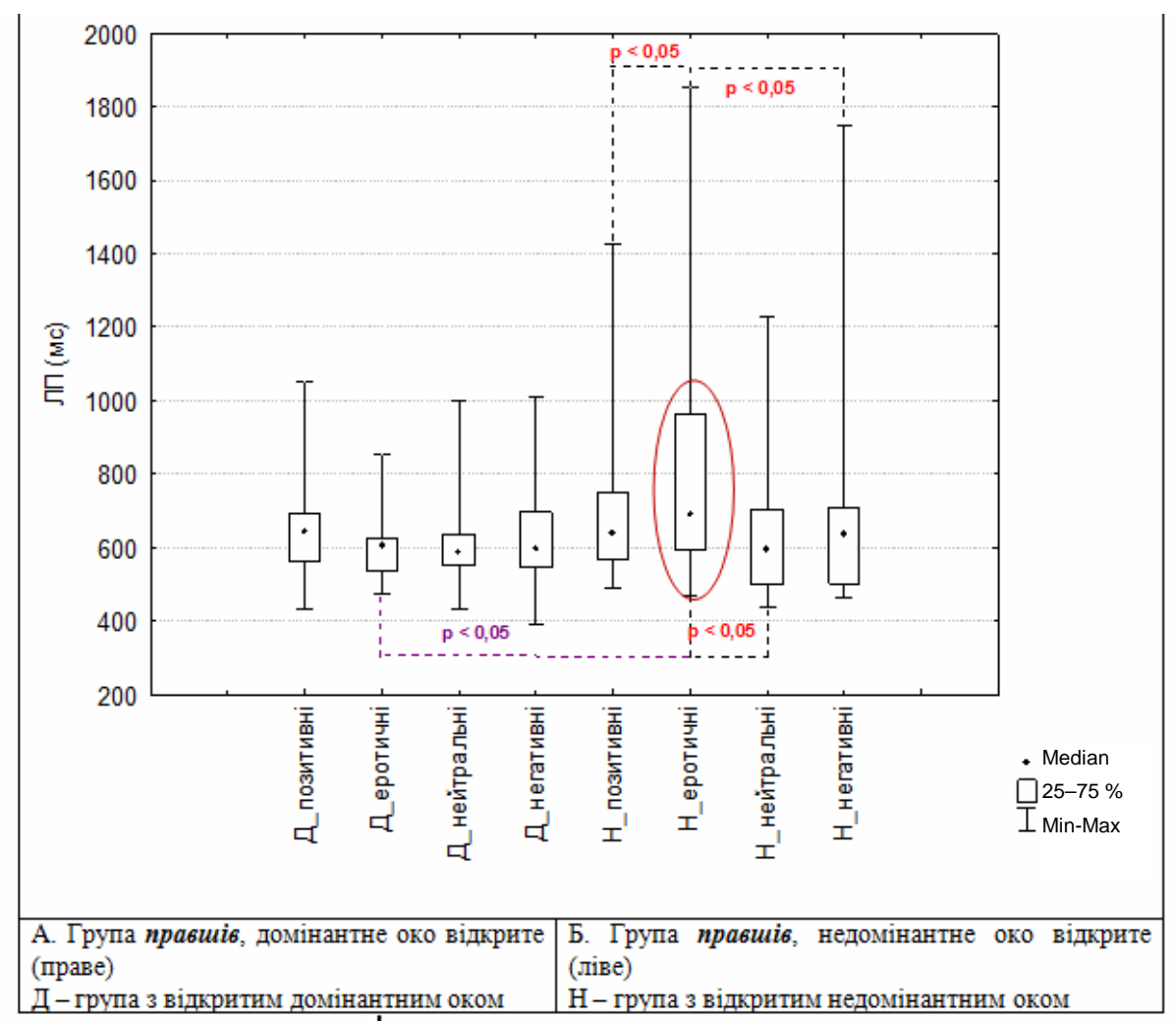

Рис.1. Латентний період реакиії правшів лівою рукою на нейтральні слова з відкритим домінантним (A) та недомінантним оком (Б) під час чотирьох тестів 
Із рис. 1 Б видно, що під час сприйняття нейтрального слова в групі з відкритим недомінантним оком ЛП реакції лівої руки (іпсілатеральної до відкритого ока) був достовірно довший на фоні еротичної картинки, ніж на фоні всіх іншим картинок (позитивна, нейтральна, негативна), у той час як подібна різниця відсутня в групі з відкритим домінатним оком (рис. 1 А). Очевидно, що фон має значення, але лише в умовах сприйняття через недомінантне око, оскільки нейтральне слово саме по собі не викликає захоплення уваги в обстежуваних $[22,23] .3$ огляду на те, що картинка була еротичного характеру, можна припустити, що права півкуля, відповідальна за аналіз емоційного компонента [24], була залучена в обробку стимулу в цих умовах, що відображається в подовженні ЛП лівої руки.

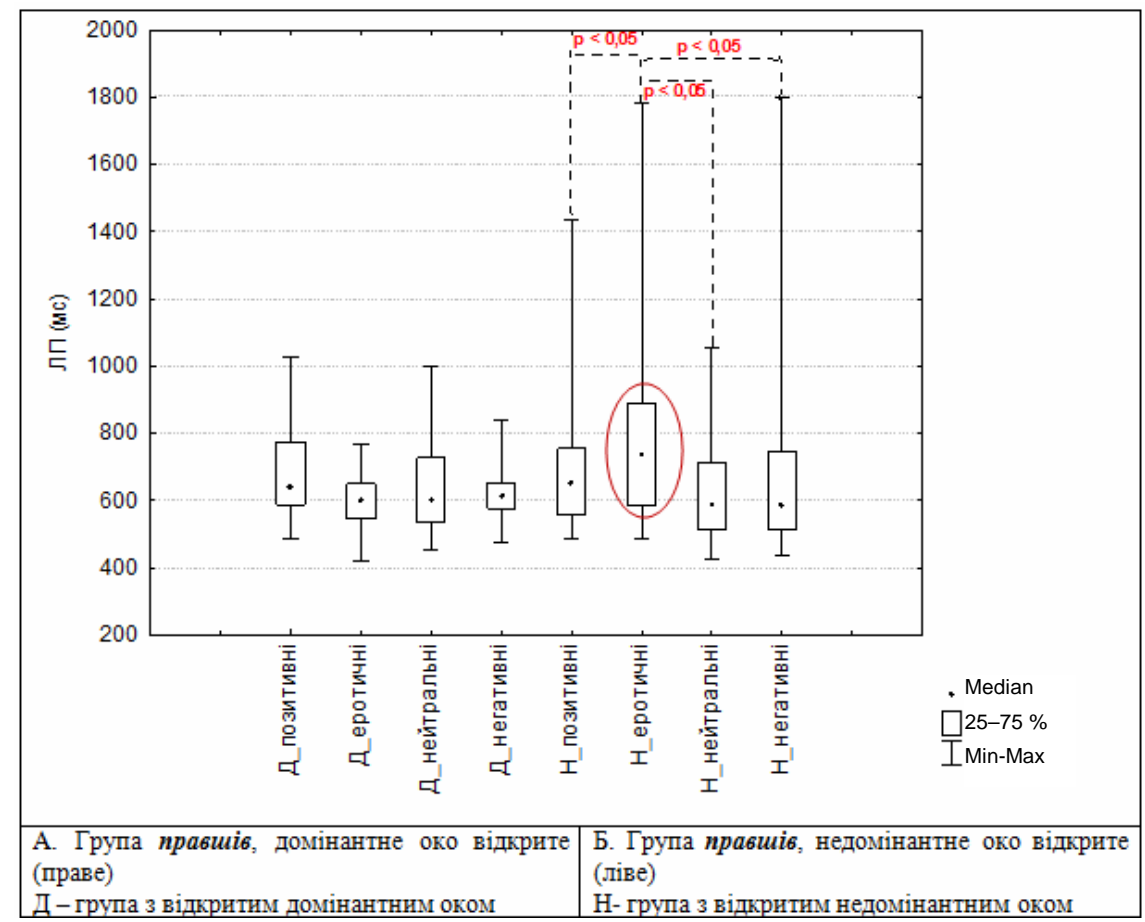

Рис. 2. Латентний період реакиії правщів правою рукою на емоціийні слова з відкритим домінантним $(A)$ та недомінантним оком (Б) під час чотирьох тестів

Схожу картину простежуємо й на рис. 2 Б: ЛП реакції правої руки на емоційні слова на фоні еротичної картинки був достовірно більший, ніж на фоні інших картинок, у той час як подібна різниця відсутня в групі з відкритим домінантним оком (рис. 2 А). Це може бути пов'язане 3 особливістю розташування мовного центру в лівій півкулі в правшів. Можна припустити, що обстежуваний звертає увагу на еротичну фонову картинку й мимовільно читає емоційне слово (залучена ліва півкуля), що відображається в подовженні часу реакції правою рукою.

Розглянемо спектральні потужності (СП) та коефіцієнти когерентності (КК) основних ритмів ЕЕГ у правшів під час різних тестів. У групі з відкритим домінантним оком (рис. 3 А) відзначається ріст СП бета-ритму в більшості відведеннях та фактично у всіх тестах, окрім Т3, де фоном виступала нейтральна картинка. На рис. 3 Б простежуємо збільшення коефіцієнта когерентності (КК) високочастотного й низькочастотного бета-ритму, у Т1 - у тім'яно-центрально-фронтальних парах обох півкуль, у Т2 - у потиличних парах обох півкуль, у правій півкулі від потиличних до фронтальних пар, у лівій префронтально-фронтальній парі, у Т4 - у центрально-фронтальних парах, у лівих префронтально-фронтальній та тім'яно-центральній парах. Ріст високочастотних компонентів ЕЕГ пов' язують із виконанням когнітивних завдань та з концентрацією уваги [25]. Ріст СП тета-ритму у всіх тестах свідчить про залучення неспецифічних мереж пам'яті та зростання загального емоційного напруження [26], що й не дивно, оскільки емоційний Струп-тест зазвичай має таку реакцію $[17,18,27]$. Слова в тесті мимовільно читаються та запам'ятовуються [17]. Оскільки потужним відволікаючим 
фактором у всіх завданнях була фонова картинка, то можна припустити, що еротичні й негативні картинки (Т2 та Т4), викликаючи високий рівень активації, вимагають більше мозкових ресурсів для забезпечення точності виконання завдання з мінімальною кількістю помилок. Нами не отримано достовірної різниці в кількості помилок між чотирма тестами. Також простежується ефект навчання [28], оскільки під час Т3 із фоновою картинкою, що не несе загрозливої чи цікавої інформації, не спостерігаємо збільшення СП або КК бета-ритму, що свідчить про виникнення ефективної стратегії виконання завдання. Звертає на себе увагу той факт, що Т3 і Т4 й меншою мірою Т1 супроводжувалися міжпівкульними змінами когерентності тета-ритму, що не простежено під час Т2.

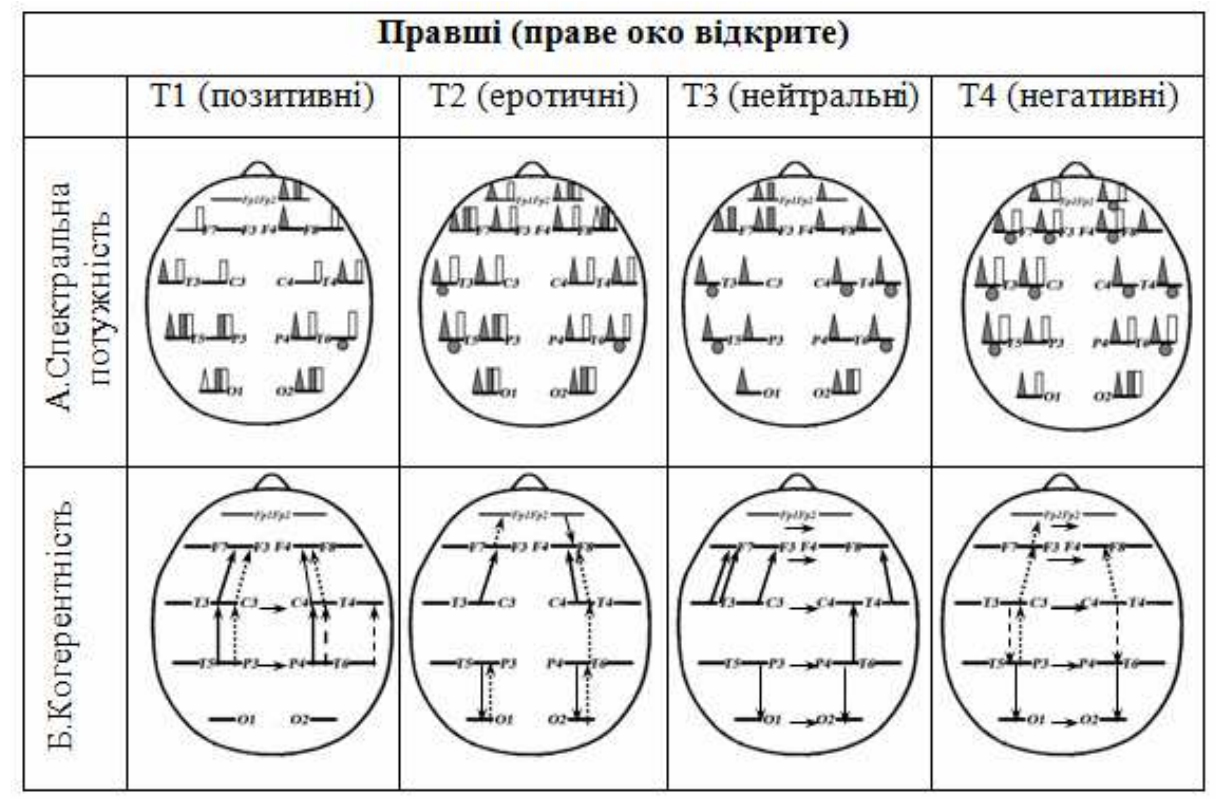

Рис. 3. Топокарти значущчих відмінностей спектральної потужності (CП) та когерентності $($ К) основних ритмів ЕЕГ праворуких обстежуваних з відкритим домінантним правим оком під час різних тестів відносно стану спокою (див. рис. 3)

А. Горизонтальною лінією вказана відсутність вірогідної різниці між значеннями СП у відповідних відведеннях. Знак над рисочкою - зростання показника, знак під рисочкою - зниження показника.

$\triangle$ - зміни СП тета-діапазону; $\bigcirc$ - зміни СП альфа-діапазону; [ ] - зміни СП низькочастотного та високочастотного піддіапазонів бета-ритму;

Б. Стрілка, направлена вгору (або вліво) - зростання показника когерентності; стрілка, направлена вниз (або вправо) - зниження показника когерентності.

- зміни показника когерентності в тета-діапазоні

- - зміни показника когерентності в альфа-діапазоні

- - - зміни показника когерентності в низькочастотному бета-діапазоні,

......- зміни показника когерентності у високочастотному бета-діапазоні.

Тонка смуга - коефіцієнт когерентності >0,5.

Товста смуга- коефіцієнт когерентності >0,7.

У групі правшів, які виконувала завдання з використанням недомінантного лівого ока (рис. 4 А), простежуємо ефект навчання, що відзначаємо в зменшенні зон активації. Якщо реакція на Т1 схожа в групах із відкритим домінантним і недомінантним оком, то далі в Т2, Т3 та Т4 - менше змін, те саме можна сказити й про когерентність, але тут у Т2 також відзначаємо міжпівкульну зміну когерентності тета-ритму (рис. 4 Б), чого не було в групі з відкритим домінантним оком.

Отже, у групі правшів із відкритим домінантним оком концентрація уваги на зосередженість на точності виконання завдання тривала протягом всіх чотирьох тестів (із деяким послабленням під час T3), ефект навчання від багаторазового проходження емоційного Струп-тесту не простежуємо. Оскільки різниці в ЛП реакції для однакових слів і однакових рук на фоні різних за валентністю картинок не спостерігали, можна припустити, що обстежувані в цій групі намагались ігнорувати нерелевантне до завдання зображення. У групі з відкритим недомінантним оком помічали захоплення уваги нерелевантним до завдання фоном з емоційним навантаженням. 


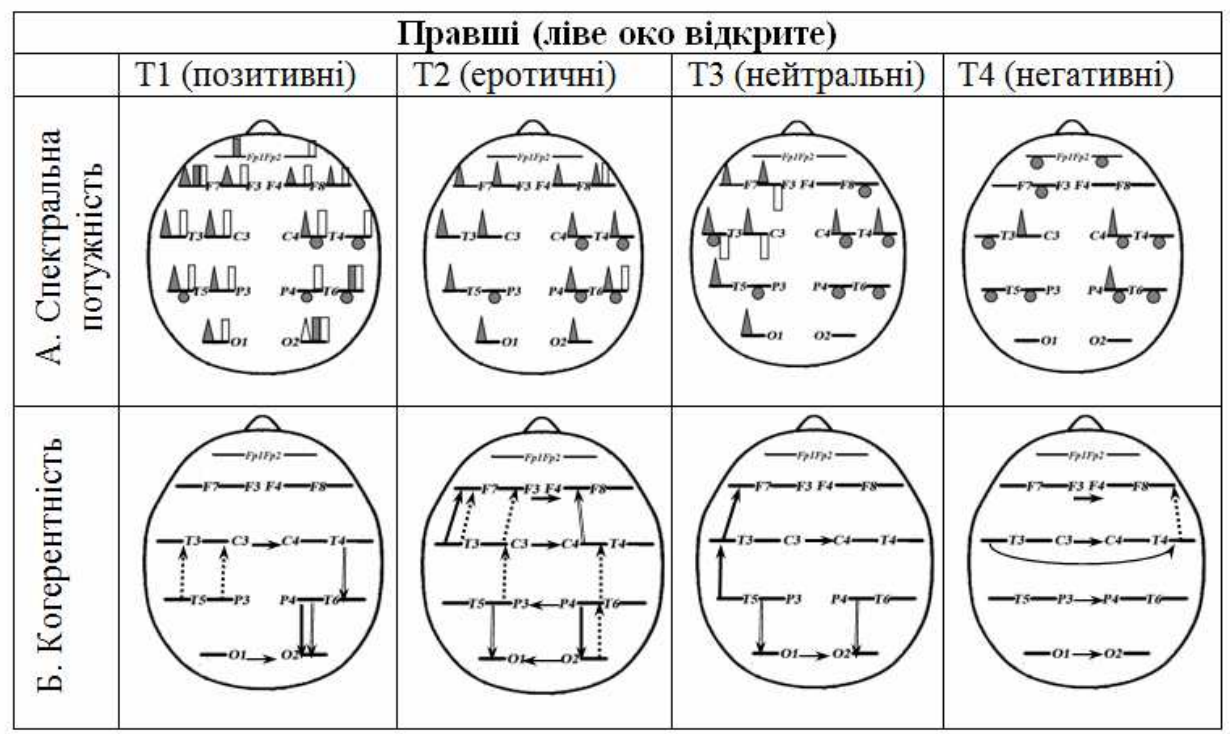

Рис. 4. Топокарти значущих відмінностей спектральної потужності (СП) та когерентності (К) основних ритмів ЕЕГ праворуких обстежуваних із відкритим недомінантним лівим оком під час різних тестів відносно стану спокою (див. рис. 3)

У групі лівшів (рис. 5 Б) простежуємо достовірно менший ЛП реакції правої (не ведучої) руки на нейтральне слово на фоні нейтральної картинки, ніж на фоні всіх інших картинок, як у групі 3 відкритим домінантним оком, так і в групі 3 відкритим недомінантним оком. Можна зробити припущення, що в таких умовах аналіз зображення на картинках (T1,T2,T4) інтерферує з аналізом семантичного значення слова, що для групи 3 відкритим недомінантним оком навіть може індукувати останнє або ж підсилювати його, оскільки ЛП реакції загалом довший у групі з відкритим

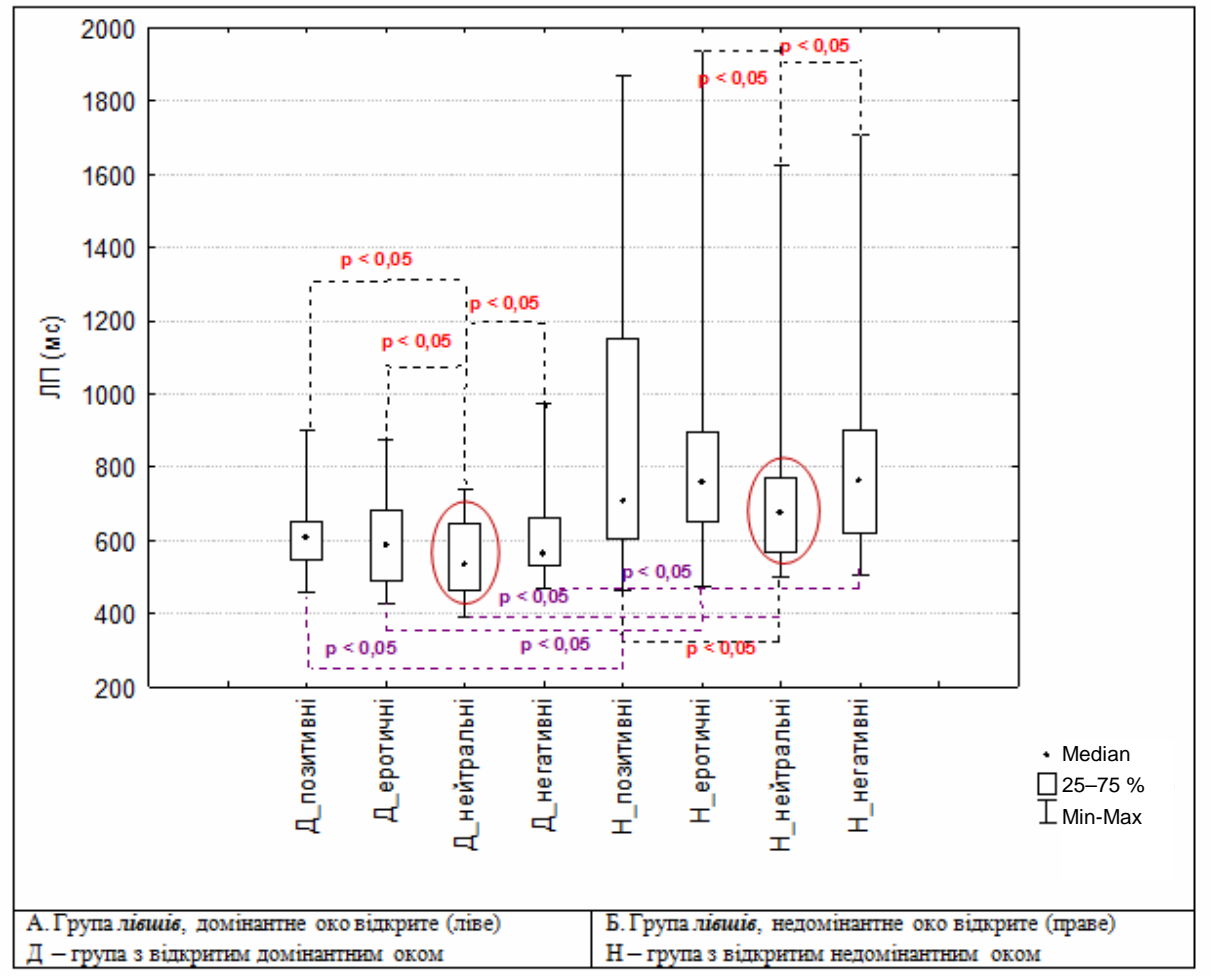

Рис. 5. Латентний період реакції лівшів правою рукою на нейтральні слова з розплющеним домінантним (A) та недомінантним оком (Б) під час чотирьох тестів 
недомінантним оком, ніж у групі з відкритим домінантним (рис. 5; 6). Відомо, що нейтральна картинка, згідно з міжнародною базою афективних зображень IAPS, не викликає ніяких емоцій чи будь-якого збудження (arousal) в обстежуваних, тому мозок не сприймає іiї для аналізу, на відміну від всіх інших використаних блоків картинок (позитивні, еротичні, негативні) [21].

Згідно 3 даними, отриманими 3 використанням методики викликаних потенціалів, емоційна модуляція розподілення ресурсів уваги під час демонстрації зображень IAPS відбувається на 550 мс [3], у той час як у групі лівшів із відкритим домінантним оком (рис. 5 А) ЛП відповіді правою рукою на нейтральне слово становить 529 [473; 552] мс, що свідчить про відсутність впливу нейтральної картинки на обстежуваних за таких умов. Аналогічну ситуацію простежуємо для лівої руки при реакції на емоційне слово (рис. 6 А), - ЛП період реакції складає 534 мс [393; 742]. Із рис. 7 Б видно зниження коефіцієнта когерентності альфа-ритму в правій потилично-тім'яній парі у всіх тестах, у T1 білатерально, що може бути свідченням відсутності читання слова в групі 3 домінантним відкритим лівим оком, оскільки відомо, що зв'язки під час читання переважно локалізуються в потиличних,

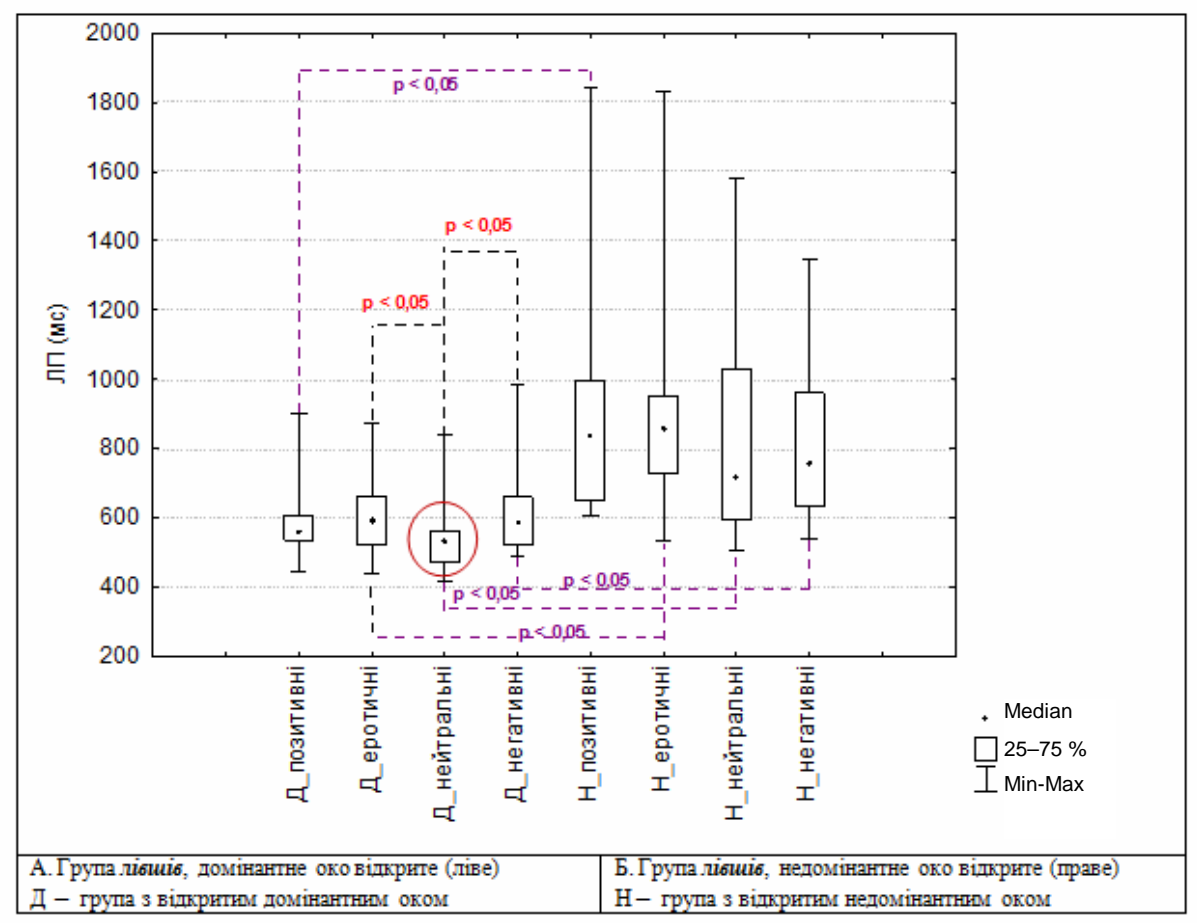

Рис. 6. Латентний період реакції лівщів лівою рукою на емоційні слова з відкритим домінантним (A) та недомінантним оком (Б) під час чотирьох тестів

скроневих і тім'яних зонах на частотах альфа-ритму [20]. На рис. 7 А спостерігаємо поступовий ефект звикання та впрацьовування, що виражається в зменшенні зон активації поступово від Т1 до Т4.

У групі, яка виконувала завдання з відкритим недомінантним оком (рис. 8 А), ефект звикання майже не простежується, генералізоване зростання СП тета-ритму свідчить про емоційне напруження обстежуваних. Розподіл когерентних зв'язків (рис. 8 Б), зокрема ріст КК бета-ритму в центропарієнтальних парах у всіх тестах, окрім Т3 (нейтральна картинка), може бути пов'язаний із читанням слів і пошуком асоціацій [20]. Тим більше, медіана ЛП відповіді значно перевищує часточки модуляції (550 мс) розподілення ресурсів уваги емоційним навантаженням фонової картинки, що свідчить про іiі вплив на виконання завдання.

Отже, правші з використанням домінантного правого ока здатні ігнорувати нерелевантну до завдання фонову емоційну інформацію. Натомість у правшів із використанням недомінантного ока фільтри уваги не спрацьовують, що відображається в збільшенні ЛП реакції на слова тесту на фоні еротичної картинки. У лівшів інформація, що потрапляе до аналізуючих структур головного мозку через домінантний зоровий канал, аналізується швидше, ніж при сприйнятті через недомінантний 


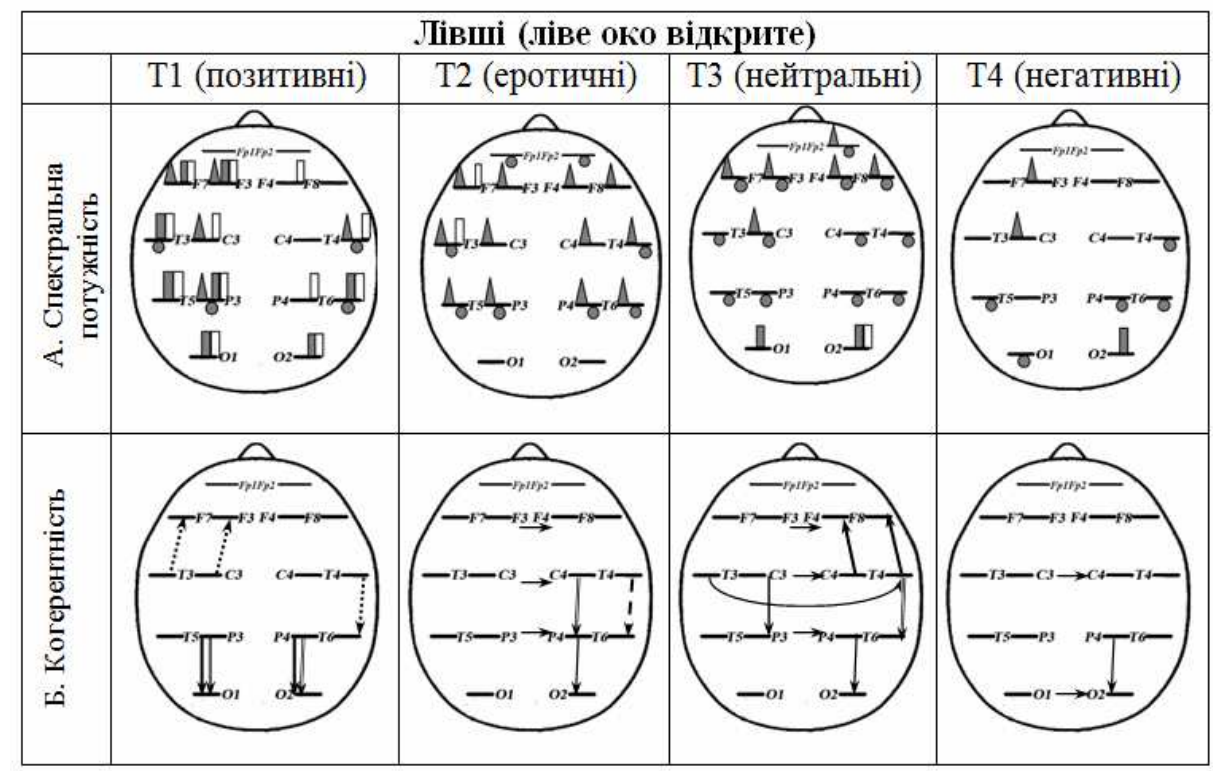

Рис. 7. Топокарти значущчих відмінностей спектральної потужності (CП) та когерентності $(K)$ основних ритмів ЕЕГ ліворуких обстежуваних із відкритим домінантним лівим оком під час різних тестів відносно стану спокою (див. рис.3)

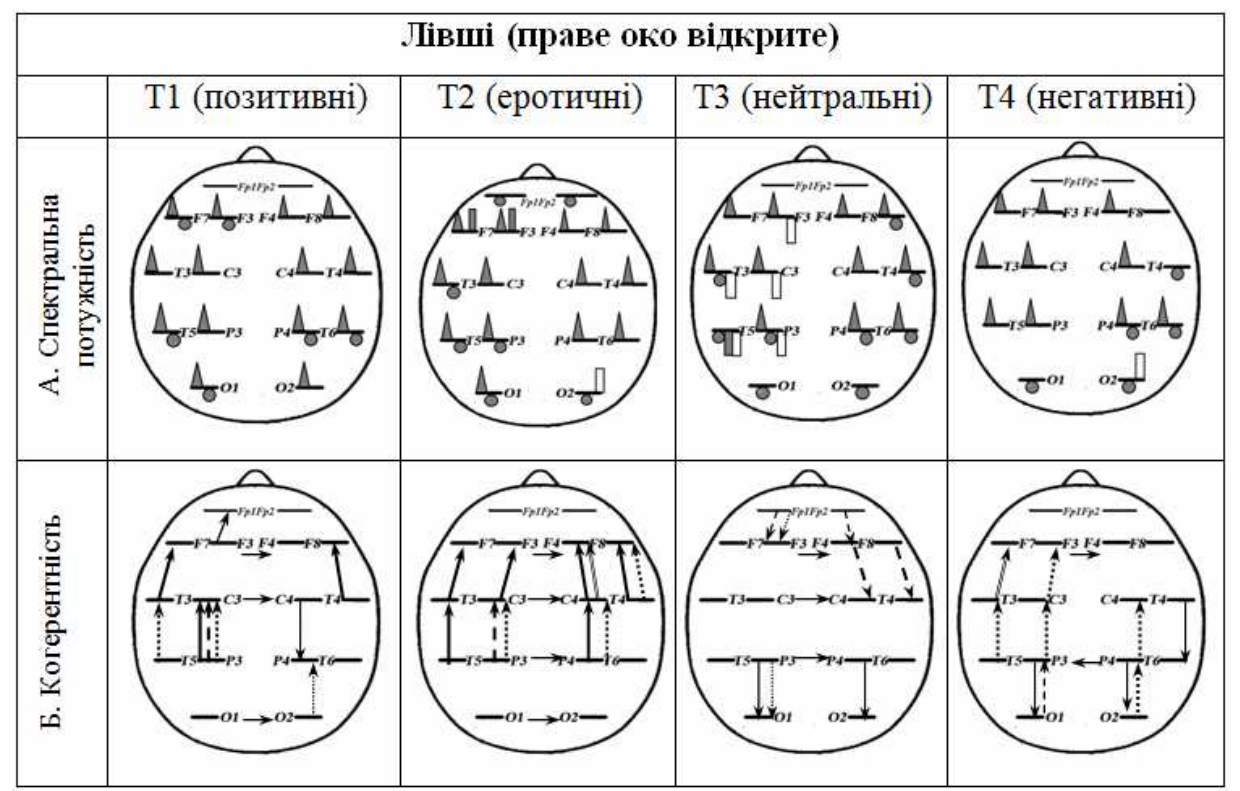

Рис. 8. Топокарти значущих відмінностей спектральної потужності (CП) та когерентності $(K)$ основних ритмів ЕЕГ ліворуких обстежуваних із відкритим недомінантним правим оком під час різних тестів відносно стану спокою (див. рис.3)

зоровий канал, що може свідчити про повне ігнорування фону обстежуваними з відкритим домінантним оком. ЛП реакції неведучої руки на нейтральне слово був достовірно більший на фоні еротичної картинки (відносно інших картинок) у групі правшів та достовірно меншим на фоні нейтральної картинки в групі лівшів. ЛП реакції ведучої руки на емоційне слово достовірно більший на фоні еротичної картинки в групі правшів і достовірно менший на фоні нейтральної картинки в групі 
лівшів. Ефект навчання простежено при сприйнятті інформації через ліве око як для лівшів, так і для правшів та, очевидно, не пов' язаний із зоровою домінантністю.

Висновки й перспективи подальших досліджень. Інформація, що поступає в аналізуючі структури головного мозку через домінантне око, аналізується швидше, ніж при сприйнятті через недомінантне око, що характерно тільки для лівшів.

Правші з використанням домінантного правого ока здатні ігнорувати нерелевантну до завдання фонову емоційну інформацію, на відміну від групи, що використовувала недомінантне око.

\section{Джерела та література}

1. Compton R. The Interface Between Emotion and Attention: A Review of Evidence from Psychology and Neuroscience / R. Compton // Behavioral and Cognitive Neuroscience Reviews. - 2003. - 2(2). - P. 115-129.

2. Fazio R. The automatic activation of attitudes On Journal of Personality and Social / R. Fazio, D. Sanbonmatsu, M. Powell, F. Kardes // Psychology. - 1986. - 50. - P. 229-238.

3. Bekhtereva V. Attentional bias to affective faces and complex IAPS images in early visual cortex follows emotional cue extraction / V. Bekhtereva, M. Craddock, M. Müller // Neuroimage. - 2015. - 15(112). P. 254-66.

4. Min-Ki Kim A Review on the Computational Methods for Emotional State Estimation from the Human EEG / Min-Ki Kim, Miyoung Kim, Eunmi Oh, Sung-Phil Kim // Comput Math Methods Med. - 2013. - 2013. P. 573734.

5. Balconi M. Brain oscillations and BIS/BAS (behavioral inhibition/activation system) effects on processing masked emotional cues. ERS/ERD and coherence measures of alpha band / M. Balconi, G. Mazza // International Journal of Psychophysiology. - 2009. - 74(2). - P. 158-165.

6. Balconi M. EEG correlates (event-related desynchronization) of emotional face elaboration: a temporal analysis / M. Balconi, C. Lucchiari // Neuroscience Letters. - 2006. - 392(1-2). - P. 118-123.

7. Davidson R. J. Anterior cerebral asymmetry and the nature of emotion / R. J. Davidson // Brain and Cognition. - 1992. - 20(1). - P. 125-151.

8. Gotlib I. H. Frontal EEG alpha asymmetry, depression, and cognitive functioning / I. H. Gotlib, C. Ranganath, J. P. Rosenfeld // Cognition and Emotion. - 1998. - 12(3). - P. 449-478.

9. Balconi M. Consciousness and arousal effects on emotional face processing as revealed by brain oscillations. A gamma band analysis / M. Balconi, C. Lucchiari // International Journal of Psychophysiology. - 2008. 67(1). - P. 41-46.

10. Keil A. Effects of emotional arousal in the cerebral hemispheres: a study of oscillatory brain activity and event-related potentials / A. Keil, M. M. Müller, T. Gruber, C. Wienbruch, M. Stolarova, T. Elbert // Clinical Neurophysiology. - 2001. - 112(11). - P. 2057-2068.

11. Müller M. Processing of affective pictures modulates right-hemispheric gamma band EEG activity / M. M. Müller, A. Keil, T. Gruber, T. Elbert // Clinical Neurophysiology. - 1999. - 110(11). - P, 1913-1920.

12. Aftanas L. I. Analysis of evoked EEG synchronization and desynchronization in conditions of emotional activation in humans: temporal and topographic characteristics / L. I. Aftanas, N. V. Reva, A. A. Varlamov, S. V. Pavlov, V. P. Makhnev // Neuroscience and Behavioral Physiology. - 2004. - P. 34(8). - P. 859-867.

13. Aftanas L. I. Affective picture processing: event-related synchronization within individually defined human theta band is modulated by valence dimension / L. I. Aftanas, A. A. Varlamov, S. V. Pavlov, V. P. Makhnev, N. V. Reva // Neuroscience Letters. - 2001. - 303(2). - P. 115-118.

14. Sammler D. Music and emotion: electrophysiological correlates of the processing of pleasant and unpleasant music / D. Sammler, M. Grigutsch, T. Fritz, S. Koelsch // Psychophysiology. - 2007. - 44(2). - P. 293-304.

15. Miskovic V. Cross-regional cortical synchronization during affective image viewing / V. Miskovic, L. A. Schmidt // Brain Research. - 2010. - 1362. - P. 102-111.

16. Martini N. The dynamics of EEG gamma responses to unpleasant visual stimuli: from local activity to functional connectivity / N. Martini, D. Menicucci, L. Sebastiani [et al] // NeuroImage. - 2012. - 60(2). - P. 922-932.

17. Rassomagina $M$ Electrophysiological correlates of the analysis of verbal stimuli during their monocular perception / M. Rassomagina, V. Kravchenko, M. Makarchuk // Visnyk Lvivskoho universytetu. Seriya Biolohichna. 2014. - 65. - P. 348-354.

18. Rassomagina M. Electrophysiological correlates of monocular dominant eye perception of verbal stimuli in emotional Stroop-tes. Lietuvos mokslu akademija / M. Rassomagina, V. Kravchenko, M. Makarchuk // Biolojia. - 2014. - № 60 (2). - P. 79-95.

19. Brahina N. The functional asymmetry of the human / N. Brahina, T. Dobrohotova // Medicine. - 1998. P. 240.

20. Nikolaev A. The cortical interactions in short time intervals during the search for verbal associations / A. Nikolaev, G. Ivanitskiĭ, A. Ivanitskiǐ // Zh Vyssh Nerv Deiat Im I P Pavlova. - 2000 Jan-Feb. - 50(1). - P. 44-61. 
21. Bradley M. M. The international affective picture system (IAPS) in the study of emotion and attention in: Handbook of Emotion Elicitation and Assessment (eds.) / M. M. Bradley, P. J. Lang ; Oxford Univ. Press. Oxford ; New York, 2007. - P. 29-46.

22. Abbassi E. Processing the emotions in words: The complementary contributions of the left and right hemispheres / E. Abbassi, K. Kahlaoui // Cogn Affect Behav Neurosci. - 2011 - Sep; 11(3). - P. $372-85$.

23. Compton R. Paying attention to emotion: An fMRI investigation of cognitive and emotional Stroop tasks / R. Compton // Cogn Affect Behav Neurosci. - 2003. - 3(2). - P. 83-84; 87-93.

24. Davidson R. Anterior cerebral asymmetry and the nature of emotion / R. Davidson // Brain and Cognition. 1992. - 20. - P. 125-151.

25. Engel A. Beta-band oscillations-signalling the status quo? / A. Engel, P. Fries // Curr Opin Neurobiol. - 2010. 20(2). - P. 156-165.

26. Putman P. EEG theta/beta ratio in relation to fear-modulated response-inhibition, attentional control, and affective traits / P. Putman, van J. Peer, I. Maimari, van der S. Werff // Biol Psychol. - 2010. - Feb. - 83(2). - P. 73-8.

27. Rassomagina M. Electrical brain activity during monocular presentation of verbal stimuli in the emotional Stroop-test / M. Rassomagina, V. Kravchenko // Visnyk of Taras Shevchenko Kyiv National University. Problems of regulation of physiological functions. - 2013. - 16. - P. 37-41.

28. Kutcenko T. Learning effect during repeatedly passing emotional Stroop test / T. Kutcenko, N. Fylymonova, O. Novycka // Visnyk of Taras Shevchenko Kyiv National University. Biology. - 2010. - 55. - P. 30-32.

Бондаренко (Рассомагина) Мария, Бондаренко Александр, Кравченко Виктория, Макарчук Николай. ЭЭГ анализ распределения внимания у левшей и правшей при прохождении эмоционального Струптеста на фоне изображений ИАPS. Оценивали спектральную мощность и коэффициент когерентности основных ритмов ЭЭГ (тета, альфа, бета-низкочастотный, бета-высокочастотный) во время эмоционального Струп-теста на фоне изображений ИАРS у левшей и правшей с открытым доминантным и недоминантным глазом. Информация, попадающая в анализирующие структуры головного мозга через доминантный зрительный канал, анализируется быстрее, чем при восприятии через недоминантный зрительный канал, что характерно только для левшей. Были показаны достоверные изменения ЛП реакции недоминантной руки на нейтральные слова и доминантной руки на эмоциональные слова как для правшей, так и для левшей. Согласно ЭЭГкоррелятов эффект обучения прослеживается при восприятии информации через левый глаз как для левшей, так и для правшей.

Ключевые слова: ИAPS, эмоциональный Струп-тест, доминантный глаз, недоминантный глаз.

Bondarenko (Rassomagina) Maria, Bondarenko Alexander, Kravchenko Victoriya, Makarchuk Mukola. EEG Analysis of the Distribution of Attention in Left-handers and Right-handers During Emotional Stroop-test on the Background of IAPS Images. Evaluated spectral power and coherence factor of the main EEG rhythms (theta, alpha, beta low-frequency, beta high-frequency) during the emotional Stroop-test on the background of IAPS images in left-handers and right-handers during perception through dominant and nondominant eye. Information that comes to analyzing structures of the brain through the dominant visual channel analyzed faster than that comes through the nondominant visual channel that is typical only for left-handers. Significant changes were shown for LP reactions of the nondominant hand on the neutral words and the dominant hand on the emotional words for both right-handers and left-handers. According to the EEG-correlates learning effect is present during perception of information through the left eye for left-handers and right-handers.

Key words: IAPS, emotional Stroop-test, dominant eye, nondominant eye.

Стаття надійшла до редколегії

08.11.2015 p.

УДК 636.4:612.017:612.176:547.992:577.164.2

Оксана Бучко

\section{Вільнорадикальні процеси в організмі свиней під дією біологічно активних добавок}

Біологічно активна добавка «Гумілід» у комплексі з аскорбіновою кислотою викликає гальмування вільнорадикальних процесів (зниження вмісту гідропероксидів ліпідів, карбонільних груп протеїнів і ТБК-активних

() Бучко O., 2015 